\title{
A kadáverdonor-vesék elfogadási gyakorlatának vizsgálata a debreceni transzplantációs centrumban
}

\author{
Nagy Ildikó - Varga Anita Katalin - Balázsfalvi Norbert - Nemes Balázs dr. \\ Debreceni Egyetem, Általános Orvostudományi Kar, Sebészeti Intézet, \\ Szervtranszplantációs Nem Önálló Tanszék, Debrecen
}

\begin{abstract}
Bevezetés: A magyarországi vesetranszplantáció 2013 óta az Eurotransplant (ET) keretein belül zajlik. A debreceni vesetranszplantációs centrumhoz évente kb. 200 kadáverdonorvese-felajánlás érkezik, melyek 37\%-a kerül a megismert adatok alapján elfogadásra. Nem minden elfogadott vese kerül beültetésre, aminek számos oka lehet.

Célkitüzés: A debreceni szakmai gyakorlat elemzése és bemutatása reprezentatív mintán.

Módszer: A debreceni centrumhoz 2016. november és 2020. március között 624 vesefelajánlás érkezett. A felajánlott vesék 37\%-a $(n=229)$ került előzetesen elfogadásra, késóbb az elfogadott vesék $63 \%$-a $(n=144)$ került beültetésre. Centrumunkban az ún. 'standard criteria', azaz tökéletes minőségû donorvesék szignifikánsan magasabb arányban kerültek elfogadásra, majd beültetésre, mint az 'extended criteria', azaz kompromisszummal vállalhatók. Az elfogadott és nem elfogadott veséket vizsgálva a KDPI (kidney donor profile index) és a KDRI (kidney donor risk index) értéke szignifikánsan magasabb volt az elutasított donorok esetében $(\mathrm{p}<0,001)$.

Eredmények: Elemeztük, hogy a felajánlott, de a centrum által nem beültetett donorveséket más ET-centrumban elfogadták-e. Látható, hogy a felajánlott 624 donorvese közül 144 Debrecenben, 313 pedig más ET-centrumban került beültetésre, viszont 167 vese beültetése egyik ET-centrumban sem történt meg (discarded organ). A 36-85 KDPI-értékkel rendelkező csoportból került beültetésre a legtöbb donorvese (180 vese) más ET-centrumban. A Debrecenben beültetett kadáverdonor-vesék KDPI- és KDRI-értéke szignifikánsan alacsonyabb volt a nekünk felajánlott, majd máshol beültetett vesékhez képest.

Következtetés: Összességében elmondható, hogy a debreceni centrumban a magas rizikócsoportba tartozó donorszervek elutasításra kerültek, miközben más centrumban a nagy részüket beültették. Ez alapján a 36-85 KDPI-értékú csoport a transzplantációs esetszám bővítésének lehetséges forrása a recipiens ismeretében.

Orv Hetil. 2021; 162(26): 1022-1028.
\end{abstract}

Kulcsszavak: veseátültetés, kiterjesztett donorkritériumok

\section{Analysis of the acceptance practice of deceased donor kidneys in a single Hungarian transplant centre}

Introduction: Kidney transplantation in Hungary is carried out via Eurotransplant (ET). Our centre in Debrecen receives around 200 kidney offers a year, of which $37 \%$ are accepted. Not all accepted kidneys are transplanted, which can be a result of a number of causes.

Obejctive: A debreceni szakmai gyakorlat elemzése és bemutatása reprezentatív mintán

Method: Between November 2016 and March 2020, the centre of Debrecen received 624 kidney offers. 37\% $(n=229)$ of the offered kidneys got preliminarily accepted, of which $63 \%(n=144)$ were transplanted later. In our centre, standard criteria donor kidneys were accepted and transplanted in significantly higher rate, than extended criteria donor kidneys. Looking at accepted and rejected kidneys, KDPI and KDRI values were significantly higher in the case of the refused ones $(\mathrm{p}<0.001)$.

Results: Part of our assessment is to analyze whether kidneys offered to and refused by us got accepted in other transplant centres. In the examined period, of the 624 kidneys offered to our centre 144 were transplanted in Debrecen, 313 were transplanted in other ET centres, while 167 were not transplanted at all (discarded organ). The majority of transplanted kidneys in other ET centres had KDPI values between 36 and 85 (180 kidneys.) KDPI and KDRI values of kidneys transplanted in our centre were significantly lower than those that were offered to us, but got transplanted elsewhere.

Conclusion: To summarize, we can say that high-risk donor organs are refused in the transplant centre of Debrecen, while the majority of them are being transplanted in other centres. Based on this, kidneys of KDPI value between 36 and 85 are a possible source of expanding the number of transplantations, with regards to the recipient. 
Keywords: kidney transplantation, expanded donor criteria

Nagy I, Varga AK, Balázsfalvi N, Nemes B. [Analysis of the acceptance practice of deceased donor kidneys in a single Hungarian transplant centre]. Orv Hetil. 2021; 162(26): 1022-1028.

(Beérkezett: 2021. március 18.; elfogadva: 2021. április 13.)

\begin{abstract}
Rövidítések
$\mathrm{BMI}=($ body mass index $)$ testtömegindex $\mathrm{CAPD}=($ continu ous ambulatory peritoneal dialysis) folyamatos ambuláns peritonealis dialízis; $\mathrm{CIT}=($ cold ischemic time $)$ hidegischaemiás idő; $\mathrm{DCD}=($ donation after circulatory death $)$ nem dobogó szívü halott donációja; DGF = (delayed graft function) későn induló graftfunkció; DSA = donorspecifikus antitest; $\mathrm{ECD}=$ (expanded criteria donor) kiterjesztett kritériumú donáció; ENIS $=($ Eurotransplant Network Information System $)$ Eurotransplant Hálózati Információs Rendszer; ESP = Eurotransplant Senior Program; ESRD = (end-stage renal disease $)$ végstádiumú vesebetegség; $\mathrm{ET}=$ Eurotransplant; $\mathrm{GFR}=$ glomerulusfiltrációs ráta; HLA = (human leukocyte antigen) humán leukocytaantigén; KDPI = (kidney donor profile index $)$ vesedonorprofil-index; KDRI $=($ kidney donor risk index $)$ vesedonor kockázati index; MFI = (mean fluorescence intensity) átlagos fluoreszcenciaintenzitás; OPTN = (Organ Procurement and Transplantation Network) Szervbeszerzési és Transzplantációs Hálózat; PRA = panelreaktív antigén; SCD = (standard criteria donor) standard kritériumú donáció; $\mathrm{SD}=$ standard deviáció; UNOS = (United Network for Organ Sharing) az Egyesült Államok Kongresszusa által 1984-ben létrehozott szervbeszerzési és transzplantációs hálózat
\end{abstract}

A veseelégtelenség (end-stage renal disease, ESRD) incidenciája világszerte folyamatosan növekszik. A transzplantációk számát korlátozza a világszerte jellemző donorszervhiány. A transzplantációs esetszám növelhető a donorként elfogadható szervek funkcionális kritériumainak kiterjesztésével (extended criteria donation, ECD): ezáltal a betegek várólistán és dialízisen eltöltött ideje lerövidíthető, ami a veseátültetést követő grafttúlélésre is kedvező hatással bír [1-3].

Számos kritériumrendszert fejlesztettek ki az elhunyt donorokból (deceased donor) származó vesék minőségi értékelésére, melyek a graftelégtelenség kockázatát igyekeznek megbecsülni [4]. Ezek közül az egyik legismertebb az SCD (standard criteria donor), ECD donor fogalma.

Az UNOS (United Network for Organ Sharing) meghatározása alapján az ECD kritériumai: a donor életkora $\geq 60$ év, vagy ha a donor életkora >50 év, és a következók közül legalább két rizikótényező teljesül: a donor anamnézisében szerepel hypertonia, a szérumkreatinin a szervkivételt megelőzően $>1,5 \mathrm{mg} / \mathrm{dl}$, továbbá az agyhalál cerebrovascularis esemény miatt következett be $[5,6]$.

$\mathrm{Az}$ ECD-kritériumrendszer mellett a donorvesék minőségi megítélésére a KDPI- (kidney donor profile index) és a KDRI- (kidney donor risk index) kritériumrendszer is használható, mely az ECD-kritériumrendszer továbbfejlesztése az Egyesült Államokban. Ez 10 donorfaktoron alapul, melyek segítségével a donorvese minőségének pontosabb megítélése biopszia nélkül is megtörténhet [4].

A KDRI a következő 10 paraméter segítségével számítható ki: a donor életkora, testmagassága, testsúlya, etnikuma, az agyhalál oka, szérumkreatinin-érték, az anamnézisben szereplő hypertonia és diabetes, továbbá a hepatitis C-vírus-status, illetve DCD- (donation after circulatory death) status [7].

A KDRI az adott donorvese beültetését követő graftelégtelenség relatív kockázatát jelzi a referenciadonorhoz képest. A KDRI értéke 0,5-3,5 közötti tartományon belül változhat, a referenciadonor KDRI-értéke 1. Minél magasabb a KDRI, annál rövidebb a várható grafttúlélés, azaz annál kevésbé vállalható minőségú a donorvese.

A KDPI az adott donor KDRI-értékének arányát mutatja meg egy referenciapopuláció KDRI-értékeihez viszonyítva. A referenciapopulációt az az Egyesült Államokban vezetett OPTN- (Organ Procurement and Transplantation Network) adatbázis adja, mely a megelőző év összes kadáver vesedonorának adatait tartalmazza. Minél magasabb a KDPI, az a KDRI-hez hasonlóan rosszabb veseminőséget jelez, míg az alacsonyabb KDPI-érték jobb minőségre, így magasabb várható grafttúlélésre utal $[2,4,7]$.

A magyarországi vesetranszplantáció 2013 óta az Eurotransplant (ET) keretein belül zajlik, melynek nyolc ország a tagja. A debreceni vesetranszplantációs centrumhoz évente kb. 200 kadáverdonorvese-felajánlás érkezik, melyek 37\%-a kerül az előzetes adatok alapján elfogadásra, majd az elfogadott vesék 63\%-a kerül beültetésre. A jelentett kadáver agyhalott donorok mindegyikének adatait az ET elektronikus rendszerében rögzítik, ahol intézményesített előszürés és egységes elfogadási kritériumrendszer nincs. Nem minden elfogadott vese kerül beültetésre, aminek számos oka lehet.

\section{Anyag és módszer}

2016 novembere és 2021 márciusa között a debreceni centrumhoz (a kizárási kritériumokat figyelembe véve) 624 vesefelajánlás érkezett. Ezeket elemeztük retrospektív módon. Kizártuk a 18 év alatti donorokból érkezett vesefelajánlásokat. Egy donorból esetleg több recipiensnek érkező felajánlás csak egyszer került be az adatbázis- 
ba, kivéve, ha az adott donorból származó mindkét vese felajánlásra és elfogadásra került.

$\mathrm{Az}$ anonim donoradatok gyújtése az Eurotransplant Network Information System (ENIS) rendszeréből történt. Az adatok statisztikai feldolgozásához az SPSS Statistics 20.0. szoftvert (IBM, Armonk, NY, Egyesült Államok) használtuk. A felajánlott donorvesék értékelése az ECD- (extended criteria donor) és a korábban ismertetett KDPI-, KDRI-kritériumrendszerek alapján történt.

Tanulmányunkban sor kerül a felajánlott donorvesék minőségi analízisére, bemutatjuk a debreceni centrum gyakorlatát a kadáverdonor-vesék elfogadására vonatkozóan, ennek tendenciáját, a donorvesék visszautasítási okainak részletes elemzésével, továbbá 1 éves utánkövetés során megvizsgáljuk a beültetett graftok funkcióját.

\section{Eredmények}

2016 novembere és 2020 márciusa között a debreceni centrumhoz 624 vesefelajánlás érkezett. A centrumunknak felajánlott vesék 37\%-a $(n=229)$ került előzetesen elfogadásra, később az elfogadott vesék 63\%-a (n = 144) került beültetésre.

A donorok 55\%-a férfi volt, 45\%-a nő. Az esetek 72\%ánál cerebrovascularis történés, 17\%-ánál trauma és 11\%ánál egyéb kórok vezetett az agyhalál kialakulásához. A donorok 55\%-ának anamnézisében szerepelt hypertonia, míg diabetes mellitus a donorok 15\%-ánál volt ismert. A felajánlott vesék 61\%-a ECD donorból származott.

A donorok átlagéletkora 57 év volt (SD: 13,38). A transzplantációra alkalmasnak talált (elfogadott) donorok életkora, szérumkreatinin-, valamint BMI- (body mass index) értéke szignifikánsan alacsonyabb volt a beültetésre alkalmatlannak talált (úgynevezett elutasított) donorokéhoz képest $(\mathrm{p}<0,001)$. A nemek között nem volt szignifikáns különbség (1. táblázat).

A legtöbb felajánlás Magyarországról (48\%) érkezett, de jelentős számú felajánlást kaptunk az ET többi országából is, főleg Horvátországból (30\%) és Németországból (14\%).

Az ET különböző országaiból érkező felajánlásokat áttekintve kiemelkedő, hogy a felajánlott horvát donorvesék nagy arányban ECD donorból származnak (90\%), míg a magyar és német donorok esetében az ECD donorok aránya jóval alacsonyabb (52\%). Ezzel jól korrelál, hogy a horvát donorok 73\%-a 85 feletti KDPI-értékkel rendelkezett, miközben a német és magyar donorok közül csak 25\%-nak volt 85-nél magasabb KDPI-értéke. A horvát donorok KDPI- és KDRI-értékei szignifikánsan magasabb voltak, mint a magyar és német donorokéi $(\mathrm{p}<0,001)$.

A horvát donorokból érkező felajánlások nagyrészt szervmentő felajánlás (rescue allocation) részeként jelentek meg Debrecenben, ami azt jelenti, hogy a donorszerv kivétele már megtörtént, de az elsődleges felajánlás során (egy vagy több centrumban) visszautasították. Az így már növekvő hidegischaemiás idő (CIT) miatt a szerv allokációja sürgőssé válik. Ennek hátterében a legtöbbször az áll, hogy a felajánlott donorszerv minősége erősen kompromisszumos. Így érthetőek a náluk mért magasabb KDPI/KDRI értékek.

Az SCD-vesék érthetően szignifikánsan magasabb arányban kerültek elfogadásra, majd beültetésre, mint az ECD-vesék (1. táblázat).

Debrecenben a 85 feletti KDPI-értékkel rendelkező vesék 22\%-a, a 35-85 közötti KDPI-értékkel rendelkező vesék 40\%-a, míg a 0-35 KDPI-értékkel rendelkező vesék 67\%-a került elfogadásra. Az alacsonyabb KDPIértékkel rendelkező csoportba tartozó vesék az elfogadást követően nagyobb arányban kerültek beültetésre (1. ábra).

Az elfogadott és a nem elfogadott veséket vizsgálva, az utóbbiak esetén a KDPI- és KDRI-értékek szignifikánsan magasabbak voltak ( $\mathrm{p}<0,001)$ (1. táblázat).

A donorvesék visszautasítási gyakorlatát és okait vizsgálva, a felajánlások 89\%-ában merült fel donorminőséggel kapcsolatos probléma: 13\%-nál logisztikai ok (hosszú CIT, vagy a donor és recipiens közötti nagy életkorbeli eltérés), illetve 10\%-nál immunológiai ok (HLA'mismatch' [eltérés], emelkedett PRA [panelreaktív antigén]), a recipiensben kimutatható magas DSA-érték (jellemzően 10000 MFI-érték feletti) szerepelt a visszautasítás okaként. A donorszerv elutasítása 50 esetben több, fentebb említett probléma (immunológiai, donorminőség, logisztikai) együttes fennállása miatt történt.

Részletesen áttekintve a donorvesék minőségi kritikáját, visszautasításra a donorvese úgynevezett anatómiai eltérése (a szervkivételt végző sebész által észlelt nephrosclerosis, érelmeszesedés, veseér- vagy uretersérülés,

1. táblázat |A debreceni centrumnak felajánlott donorok jellemzői

\begin{tabular}{|c|c|c|c|}
\hline & $\begin{array}{l}\text { Elfogadott } \\
\text { donorok } \\
\mathrm{n}=229\end{array}$ & $\begin{array}{l}\text { Elutasított donorok } \\
\mathrm{n}=395\end{array}$ & $\mathrm{p}$ \\
\hline Kor (év) & $52($ SD 12,67) & $60($ SD 12,75) & 0,001 \\
\hline Nem (férfi) & $119(52 \%)$ & $227(57 \%)$ & 0,182 \\
\hline $\operatorname{BMI}\left(\mathrm{kg} / \mathrm{m}^{2}\right)$ & $26,51(\mathrm{SD} 4,44)$ & $27,80(\mathrm{SD} 4,75)$ & 0,001 \\
\hline $\begin{array}{l}\text { Szérumkreatinin } \\
(\mathrm{mg} / \mathrm{dl})\end{array}$ & $0,86(\mathrm{SD} 0,32)$ & $1,22(\mathrm{SD} 0,85)$ & 0,001 \\
\hline $\begin{array}{l}\text { Hypertonia } \\
(\mathrm{n}=543)\end{array}$ & $103(52 \%)$ & $238(69 \%)$ & 0,001 \\
\hline $\begin{array}{l}\text { Diabetes } \\
(\mathrm{n}=486)\end{array}$ & $27(15 \%)$ & $68(22 \%)$ & 0,185 \\
\hline $\begin{array}{l}\text { Az agyhalál oka: } \\
\text { cerebrovascularis } \\
\text { esemény }\end{array}$ & $143(62 \%)$ & $306(77 \%)$ & 0,001 \\
\hline $\operatorname{ECD}(n=606)$ & $103(46 \%)$ & $279(73 \%)$ & 0,001 \\
\hline KDRI & $1,20($ SD 0,37) & $1,54(\operatorname{SD} 0,51)$ & 0,001 \\
\hline KDPI & $60,9(\mathrm{SD} 27,63)$ & $77,57($ SD 22,67) & 0,001 \\
\hline
\end{tabular}

$\mathrm{BMI}=$ testtömegindex $; \mathrm{ECD}=$ kiterjesztett kritériumú donáció; KDPI = vesedonorprofil-index; $\mathrm{KDRI}=$ vesedonor kockázati index; $\mathrm{SD}=$ standard deviáció 


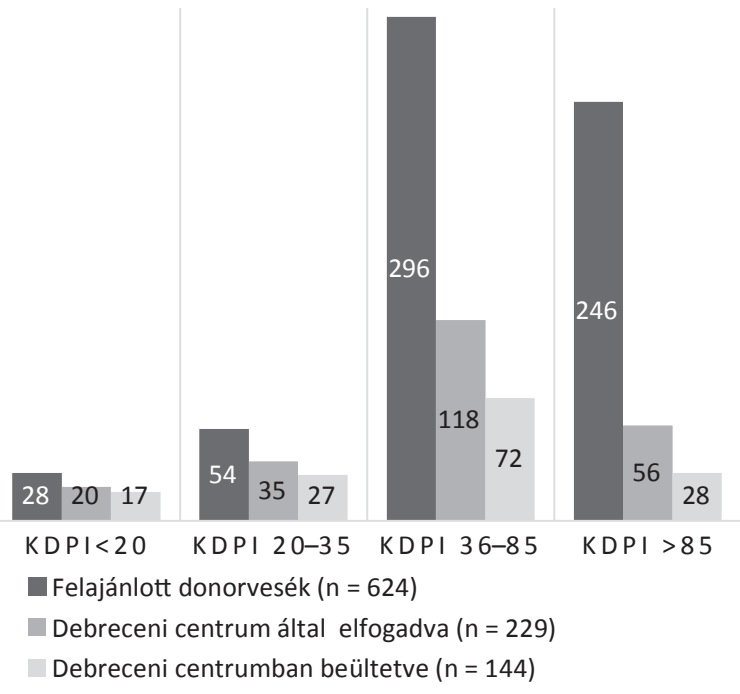

1. ábra

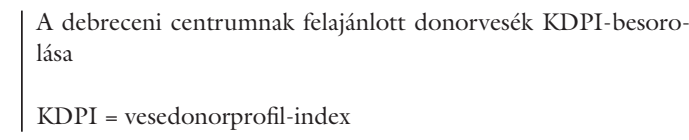

vagy a beültetést kockázatossá tevő elváltozás), a donor proteinuriája, emelkedett kreatinin- és ureaértékek miatt került sor a leggyakrabban, de magas számban jelent meg a donornál a megfigyelési periódus alatt igazolt húgyúti infekció is.

$\mathrm{Az}$ előzetesen elfogadott donorvesék 63\%-a (144 vese) került később beültetésre. A beültetés 27 esetben a recipiens alkalmatlansága (aktuálisan észlelt vagy nem rendezett társbetegség), 25 esetben a donorvesének a szervkivételt végző sebész által közölt vagy a beültető (debreceni) centrumban végzett hidegperfúzió során észlelt anatómiai problémája, 15 esetben pozitív immunológai keresztpróba és/vagy extrém magas DSA-érték miatt hiúsult meg. Emellett, az előzetesen megismert adatok birtokában történő telefonos elfogadást követően, a donornál végzett kontroll-labor alapján 6 esetben jutott tudomásunkra olyan új eredmény, amely miatt a donorszervek elfogadását visszavontuk. 12 esetben 'competitive center offer/backup offer' során érkezett hozzánk a felajánlás, melynek végeredményeként más centrum recipiense kapta meg a nekünk is felajánlott veséket, ezen eseteknél ugyanis nem csak egy centrum és recipiens részére történik meg a donorvese felajánlása (2. ábra). A szervmentő felajánlás (competitive center offer) során egy időben több centrum is megkapja a lehetőséget a donorvese elfogadására, és az elfogadást a leggyorsabban visszajelző centrum kapja meg végül a donorvesét. Az ún. „backup offer ” során pedig ugyan a donorvese egy másik recipiens részére már elfogadásra került, de az allokációs lista alapján a soron következő, egy ún. „backup recipiens” részére is felajánlásra kerül annak érdekében, hogy az első recipiens alkalmatlansága vagy pozitív keresztpróba esetén az allokációs idő csökkenthető legyen.

Tanulmányunk részeként elemeztük, hogy a Debrecennek felajánlott, de nem beültetett donorveséket más

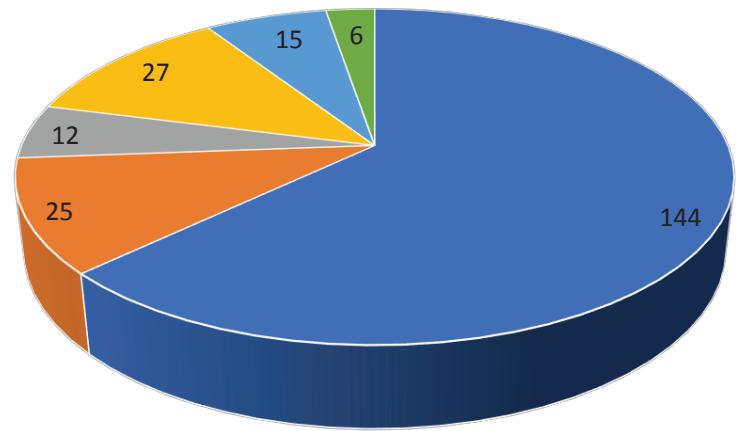

A debreceni centrumban beültetve

Veseanatómia

Backup/Competetive offer

A recipiens alkalmatlan Immunológia

Donorminőség

2. ábra $\quad$ A debreceni centrum által elfogadott donorvesék beültetésének meghiúsulását kiváltó okok

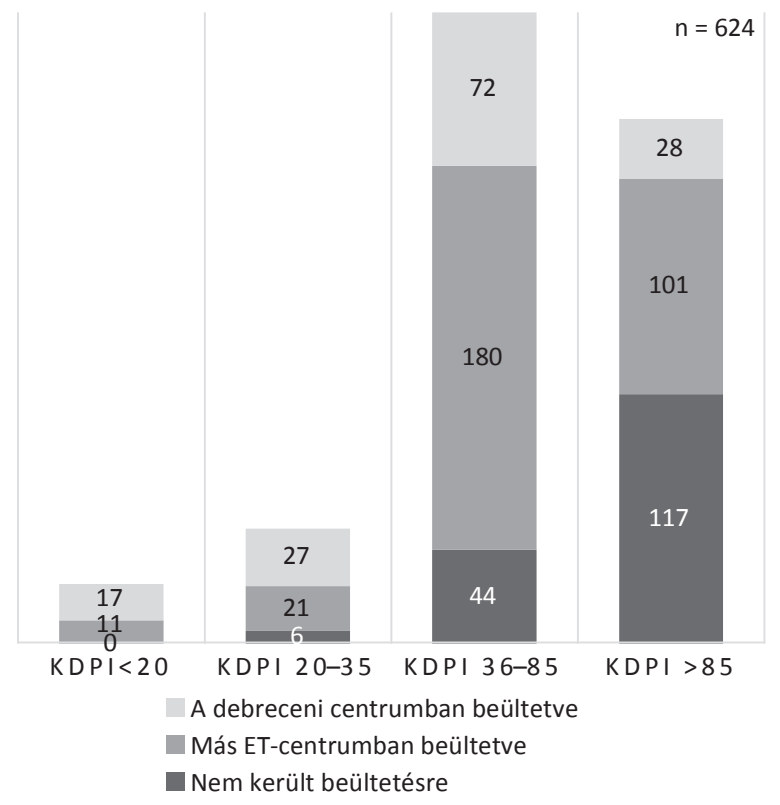

3. ábra

$$
\mid \begin{aligned}
& \begin{array}{l}
\text { A felajánlott donorvesék KDPI-besorolása a beültetés helye sze- } \\
\text { rint }
\end{array} \\
& \text { ET = Eurotransplant; KDPI = vesedonorprofil-index }
\end{aligned}
$$

centrumban milyen arányban fogadták el. A vizsgált időszakban a felajánlott 624 donorvese közül 144 vese a debreceni centrumban, 313 vese pedig más ET-centrumban került beültetésre, 167 vese beültetése viszont egyik ET-centrumban sem történt meg (discarded organ). A Debrecenben nem, de más ET-centrumban elfogadott 180 donorvese a 36-85 közötti KDPI-értékkel rendelkező csoportból került ki (3. ábra).

A Debrecenben beültetett vesék KDPI- és KDRI-értéke szignifikánsan alacsonyabb volt a Debrecenben nem elfogadott, de máshol beültetett vesékhez képest (2. táblázat).

A beültetett donorvesék múködését tekintve látható különbség volt az ECD- és az SCD-csoport között. Az SCD donorokból beültetett vesék GFR- (glomerulusfiltrációs ráta) értéke szignifikánsan magasabb volt az ECD 
\begin{tabular}{l|l} 
2. táblázat & $\begin{array}{l}\text { A felajánlott vesék ECD-, KDPI- és KDRI-értékeinek összeha- } \\
\text { sonlítása }\end{array}$
\end{tabular}

\begin{tabular}{lccc}
\hline & ECD & $\begin{array}{c}\text { KDRI } \\
\text { (átlag) }\end{array}$ & $\begin{array}{c}\text { KDPI } \\
\text { (átlag) }\end{array}$ \\
\hline $\begin{array}{l}\text { A debreceni centrumban beültetve } \\
(\mathrm{n}=144)\end{array}$ & $41 \%$ & 1,14 & 56 \\
Más ET-centrumban beültetve $(\mathrm{n}=313)$ & $62 \%$ & 1,36 & 70 \\
Nem került beültetésre $(\mathrm{n}=167)$ & $84 \%$ & 1,76 & 86 \\
\hline
\end{tabular}

ECD = kiterjesztett kritériumú donáció; ET = Eurotransplant; KDPI = vesedonorprofil-index; KDRI = vesedonor kockázati index

donorokéhoz viszonyítva, mind a 3, 6, mind a 12 hónapos értéket tekintve. Ez szintén megfigyelhető a KDPIértéknél: az l éves graftmúködést vizsgálva a magasabb KDPI-értékkel rendelkező csoportokban a GFR értéke alacsonyabb volt (4. ábra).

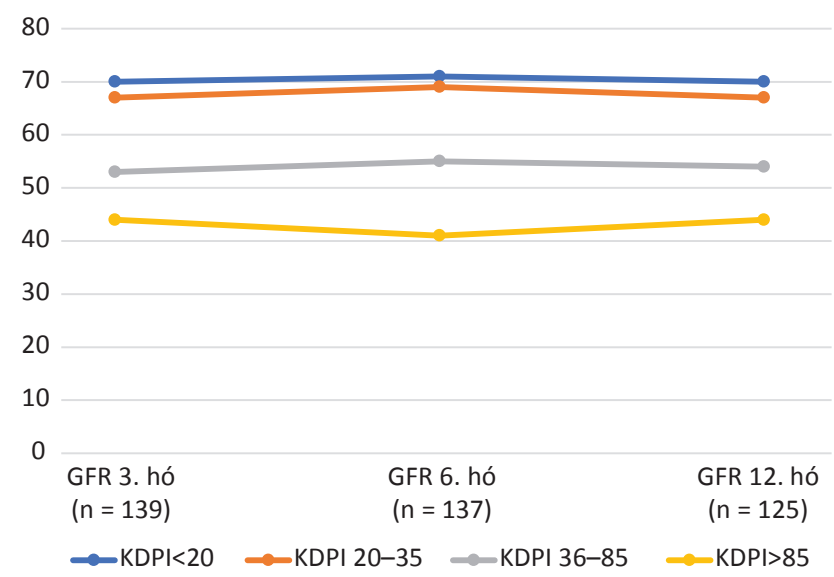

4. ábra

A debreceni centrumban a veseátültetést követő 3., 6. és 12.
hónapban mért GFR-értékek
GFR = glomerulusfiltrációs ráta; KDPI = vesedonorprofil-index

\section{Megbeszélés}

Az ET adatai alapján 2020. december 31-én a vesetranszplantációs várólistán 10827 személy szerepelt aktív statuson. 2020-ban 5650 recipiens került újonnan vesetranszplantációs várólistára, 2831 veseátültetés történt, és 608 -an haltak meg a veseátültetésre várva $(5 \%$-os mortalitás). A veseátültetés előtt a betegek $35 \%$-a $2-5$ évet töltött dialízisen, 38\%-a pedig 5 évnél is többet. A szervdonorok átlagéletkora 56 év volt [8].

A donorok demográfiai változása, a növekvő várakozási idő, a várólistán szereplő betegek és az elérhetô donorszervek száma közötti egyre növekvő deficit több innovatív megoldást is kívánt, melyek közül az egyik az ECD-szervek használatának általánossá és elfogadottá válása [9-12].

Az ECD-vesék átültetését követôen a recipiensek túlélési eredményei rosszabbak, mint az SCD-vesék átültetése esetén, de szignifikánsan jobbak, mint a hemodialí- zisben maradó betegeké. Ojo és mtsai tanulmánya alapján a marginális donorvesék transzplantációját követően a recipiensek 5 éves túlélése 77\%, miközben az SCD-vese átültetését követően $85 \%$; viszont szignifikánsan jobb, mint a várólistán szereplő hemodializált betegeké. A marginális donorvese átültetését követően a betegek várható élettartama 5,1 évvel nőtt ahhoz képest, mint ha további dialíziskezelésben részesültek volna [13]. Dahmane és mtsai kutatása alapján nem volt szignifikáns különbség az SCD- és ECD-vesék 5 éves gafttúlélése között [14], ami alapján az ECD-vesék is elfogadható grafttúlélést nyújtanak, ezért elutasításuk gondos mérlegelést igényel [15].

Az ECD-vesék átültetését követően a beültetett vese múködőképes élettartama rövidebb, mint SCD esetén, de ez még mindig jobb életkilátást kínál egyes betegeknek, mint a permanes hemodialízis-kezelés. A személyre szabott elfogadás azt jelenti, hogy ugyan egy SCD-vese múködőképes élettartama 15-20 év is lehet, de sajnos az ilyen felajánlás ritka. Egy - hamarabb érkező - ECD-vesével kimenekíthetünk például egy idősebb, szívbeteg vesebeteget 5-8 évre a múvesekezelésről. Így a cardialis dekompenzáció romlása megáll, amely a vesére várakozás évei alatt, múvesekezelés mellett folytatódhatott volna, így akár a beteg halálához vezetve. Természetesen egy még predialízises állapotban levő, gondozott vesebeteg vagy a CAPD-kezelést éppen elkezdő fiatalabb beteg esetén valóban csak alacsony KDRI/KDPI pontszámok fogadhatók el, ôk még várhatnak egy „jobb” felajánlásra.

$\mathrm{Az}$ irányelvek alapján az ECD-vesék elfogadása 60 évesnél idősebb recipienseknek, 40 évesnél idősebb diabeteses recipienseknek javasolt, illetve olyan betegeknek, akiknél arteriovenosus fistula kialakítása nem lehetséges, vagy azon betegeknek, akiknek a várható várakozási ideje meghaladja a várható élettartamukat a várólistán szervátültetés nélkül $[11,16]$. Az iránymutatás alapelve az, hogy ezáltal azok a betegek is hozzájuthatnak a veseátültetéshez, akiknek a várható élettartamuk kevesebb, mint amennyit előreláthatólag a várólistán fognak tölteni. Az etikai szabályoknak megfelelően fontos az egyensúly megteremtése az igazságosság és a klinikai hasznosság között [11].

A fentiekben nyújt segítséget az ET old for old programja (Eurotransplant Senior Program, ESP), amely biztosítja az idősebb donorvesék idősebb recipiensekhez jutását. Az ESP program 1999 óta múködik. A 65 évesnél idősebb donorszerveket 65 évnél idősebb recipienseknek allokálják. Az allokáció a HLA-egyezést nem veszi figyelembe, csak $\mathrm{AB} 0$-vércsoport-egyezés és negatív keresztpróba szükséges. Az allokáció alapja, hogy a donorszevminőségen felül minden más, a közép-hosszú távú vesemúködést negatívan befolyásoló faktort minimalizáljon. Így szempont, hogy a donorszerv ischaemiás ideje minél rövidebb legyen, azaz a lokális allokáció sorrendjét elsôsorban a donortól való földrajzi távolság, majd a recipiens várakozási ideje határozza meg. Az elfogadó centrum pedig a minél jobb HLA-egyezést veszi 
figyelembe, segítve ezzel az immunológiai kockázat csökkentését. Az akut rejekció gyakrabban fordul elő ebben a populációban, a magasabb arányú HLA'mismatch'-ből eredően, aminek következményeként fennállhat a hosszabb kórházi kezelés szükségessége, illetve a középtávú graftvesztés kockázata is magasabb. Más szerzők az idős donorok megkétszereződését tapasztalták a programon belül, aminek segítségével az idős recipiensek várakozási ideje csökkent, ezzel megerősítve, hogy az ESP hatékony allokációs rendszer az idős donorszervek felhasználására [2, 17].

A transzplantációs központoknak korlátozott idő áll rendelkezésükre, hogy döntsenek a felajánlott donorszerv elfogadásáról vagy elutasításáról. Ez a döntés a legtöbbször a döntéshozó szakemberek tapasztalatán alapszik, nincs egységes elfogadási szabályrendszer. Az, hogy egy felajánlott donorvesét elfogadnak-e, számos tényezőn alapszik. Ezek egy része nem a donorral függ össze, mint például a recipiens általános állapota, kockázati faktorai, társbetegségei és ezek aktuális állapota, a recipiens távlati lehetőségei és kockázata, ha nem történik meg aktuálisan a veseátültetés (várólista halálozás). A döntéshozó mérlegeli a donorszerv minőségét, továbbá a centrumspecifikus tényezőket (például rendelkezésre áll-e intenzív osztályos kapacitás, ha a recipiens kockázati felmérése alapján ez indokolt, vagy párhuzamosan zajló másik vagy harmadik veseátültetés). A felajánlott szerv elfogadásakor mérlegelni szükséges, hogy a beteg várakozási idejét, a klinikai állapotát is figyelembe véve, a beteg számára legközelebb mikor és milyen minőségű szerv felajánlása várható. Ilyen szempont lehet a hiperimmunizált állapot, amikor egy hosszú várakozást követően végre negatív keresztpróba mellett felajánlott donorvese (legyen bár ECD) visszautasítása után lehet, hogy évekig nem lesz újabb lehetőség. Az egyéni faktorok súlya attól függően változik, hogy milyen szerv beültetéséről kell dönteni. A donorvesék elfogadásával kapcsolatos döntés nyilvánvalóan különbözik a többi szerv (szív, máj, tüdő) elfogadásával kapcsolatos döntéstől, hiszen ezek életmentő mütétek. A veseátültetésre váró betegek állapota a vesepótló kezelésekkel fenntartható, ami arra ösztönözheti a döntéshozókat, hogy egy jobb minőségú donorvese felajánlására várjanak [15]. Ugyanakkor a vesebetegekre jellemző cardiovascularis társbetegségek (jellemzően cardiomyopathia és koszorúér-megbetegedések), valamint a progresszív perifériás érszúkület dekompenzációja gyorsabb a múvesekezelés mellett, ami miatt egy idő után alkalmatlanná válnak bármilyen mútét elvégzésére, illetve a cardialis szövődmények miatt a mortalitásuk is magasabb. Így a veseátültetés, különösen a fentebb leírt kompromisszumos elvek mentén, egy körülírható betegcsoport számára életmentő beavatkozás.

Számos kutatás készült már a veseátülttetés szív-ér rendszeri hatásairól, melyek alapján a tapasztalatok öszszességében kétoldalúak [18-20]. Veseátültetés után a cardiovascularis kockázat csökken, a veseátültetéssel járó túlélési előny a cardiovascularis betegségek redukciójá- nak tulajdonítható. Emellett azonban a szív-ér rendszeri elváltozások nem fordíthatók vissza teljesen, így az utógondozás során feladatot jelentenek a gondozó orvos számára [21]. Ebból az is következik, hogy a veseátültetést még akkor kell elvégezni, amikor a beteg cardialis társbetegségei enyhék és reverzibilisek, akár azon az áron, hogy ez ECD donorral történik.

Annak minél pontosabb meghatározása, hogy a beültetésre kerülő donorvese múködési élettartama milyen hosszú lesz, elengedhetetlen feltétele a felajánlott donorvesék elfogadásával kapcsolatos - személyre szabott döntés meghozatalában. A vesetranszplantációra várók számának növekedése ennek fontosságát még inkább növeli. A KDRI könnyen kiszámítható mutató, mely erre a célra jól felhasználható, ezáltal megkönnyíti a transzplantációs szakemberek döntési folyamatát, a lehetőségek felmérését egy adott donorvese allokációja során [9].

Zens és mtsai megfigyelése alapján a magasabb KDPIértékkel rendelkező donorvesék rövid távú eredményeit tekintve a DGF előfordulása gyakoribb volt, mint az alacsonyabb KDPI-értékkel rendelkező donorvesék esetében [22]. Ugyanakkor a DGF átmeneti állapot, amelynek rendeződése után a donorvese múködése évekig kiváló lehet.

Gandolfini és mtsai 442 marginális veseátültetést vizsgáltak Olaszországban, melynek eredménye alapján a magasabb KDPI-értékekhez rosszabb graftmúködés társult, emellett arra a következtetésre jutottak, hogy a KDPI-kritériumrendszer kifejezőbb, donorértékelést támogató eszköz, mint az életkor vagy az ECD-kritériumrendszer, de önmagában nem elegendő a szervminőség értékeléséhez, illetve ahhoz, hogy eldöntsük, egy vese elfogadható-e vagy nem $[23,24]$.

\section{Következtetés}

A debreceni centrumnak felajánlott veséket áttekintve látszik, hogy a vesék nagy százaléka ECD donorból származik, illetve a magas KDPI-értékkel rendelkező csoportba tartozik. Összességében elmondható, hogy a debreceni centrumban a magas rizikócsoportba tartozó donorszervek többségében elutasításra kerültek, miközben más centrumban a nagy részüket beültették. Ez alapján a 36-85 közötti KDPI-értékű csoport a transzplantációs esetszám bővítésének lehetséges forrása a recipiens ismeretében. Ezeknél a betegeknél az utógondozásnak van fontos szerepe. A KDRI/KDPI ismerete abban nyújthat segítséget, hogy a beteg számára hoszszabb távon milyen - személyre szabott - gyógyszerelést alkalmazzunk, illetve minimalizáljuk az egyéb vesekárosító faktorokat, hiszen „érzékenyebb” veséről van szó. Ilyenkor kerül előtérbe a vesekárosító gyógyszerek megvonása: ez vonatkozik az immunszuppresszió megfelelő és személyre szabott kialakítására, továbbá az egyéb társbetegségek (elhízás, magas vérnyomás, cukorbetegség) aktív kezelésére, amelyek sikere esetén a páciens az ECDvese mellett is megfelelő vesemúködéssel élhet. 
Összefoglalva, a KDRI hasznos eszköz a donor értékelésére és a transzplantáció utáni eredmények becslésére, és segítséget nyújthat az orvosok és a betegek számára, hogy megalapozott döntést hozzanak egy donorszerv elfogadásáról [9].

Anyagi támogatás: A közlemény megírása anyagi támogatásban nem részesült.

Szerzői munkamegosztás: N. I.: Az adatgyüjtés megszervezése, adatgyújtés, az adatok statisztikai feldolgozása, irodalomkutatás, közleményírás. N. B.: Témaválasztás, az adatgyüjtés és az eredmények ellenőrzése, véleményezése. V. A. K.: Adatgyújtés, irodalomkutatás. B. N.: Adatgyưjtés. A cikk végleges változatát valamennyi szerző elolvasta és jóváhagyta.

Érdekeltségek: A szerzőknek nincsenek érdekeltségeik.

\section{Irodalom}

[1] Wettstein D, Hamar M, Cseprekál O, et al. Machine perfusion: new opportunities in abdominal organ transplantation. [Szervkonzerválás gépi perfúzióval: új lehetőségek a hasi szervek transzplantációjában.] Orv Hetil. 2018; 159: 1882-1890. [Hungarian]

[2] Zádori G, Tarjányi VP, Szabó R, et al. Analysis of donor scoring systems in a single Hungarian transplant centre. [Donorszelekciós kritériumok vizsgálata a debreceni veseátültetési programban.] Orv Hetil. 2016; 157: 946-955. [Hungarian]

[3] Hsu CY, Vittinghoff E, Lin F, et al. The incidence of end-stage renal disease is increasing faster than the prevalence of chronic renal insufficiency. Ann Intern Med. 2004; 141: 95-101.

[4] Lee AP, Abramowicz D. Is the Kidney Donor Risk Index a step forward in the assessment of deceased donor kidney quality? Nephrol Dial Transplant. 2015; 30: 1285-1290.

[5] Florman S, Becker T, Bresnahan B, et al. Efficacy and safety outcomes of extended criteria donor kidneys by subtype: subgroup analysis of BENEFIT-EXT at 7 years after transplant. Am J Transplant. 2017; 17: 180-190.

[6] Palkoci B, Vojtko M, Fialová J, et al. Results of kidney transplantation from expanded criteria donors: a single-center experience. Int J Organ Transplant Med. 2018; 9: 1-9.

[7] OPTN. A Guide to calculating and interpreting the Kidney Donor Profle Index (KDPI). Available from: https://optn. transplant.hrsa.gov/media/1512/guide_to_calculating_interpreting_kdpi.pdf [accessed: March 1, 2021].

[8] Eurotransplant. Statistics Report Library. Available from: https://statistics.eurotransplant.org/ [accessed: March 2, $2021]$.

[9] Rao PS, Schaubel DE, Guidinger MK, et al. A comprehensive risk quantification score for deceased donor kidneys: the kidney donor risk index. Transplantation 2009; 88: 231-236.

[10] Bonsignorea P, Pagano D, Piazza S, et al. Crucial role of extended criteria donors in deceased donor single kidney transplan- tation to face chronic shortage in the heart of the Mediterranean basin: a single-center experience. Transplant Proc. 2019; 51: 2868-2872.

[11] Stratta RJ, Rohr MS, Sundberg AK, et al. Intermediate term outcomes with expanded criteria deceased donors in kidney transplantation: a spectrum or specter of quality? Ann Surg. 2006; 243: 594-601.

[12] Stratta RJ, Rohr MS, Sundberg AK, et al. Increased kidney transplantation utilizing expanded criteria deceased organ donors with results comparable to standard criteria donor transplant. Ann Surg. 2004; 239: 688-695.

[13] Ojo AO, Hanson JA, Meier-Kriesche HU, et al. Survival in recipients of marginal cadaveric donor kidneys compared with other recipients and wait-listed transplant candidates. Am Soc Nephrol. 2001; 12: 589-597.

[14] Dahmane D, Audard V, Hiesse C, et al. Retrospective follow-up of transplantation of kidneys from 'marginal' donors. Kidney Int. 2006; 69: 546-552.

[15] De Rosa P, Muscogiuri G, Sarno G. Expanded criteria donors in kidney transplantation: the role of older donors in a setting of older recipients. ISRN Transplant. 2013; 2013: 301025.

[16] Metzger RA, Delmonico FL, Feng S, et al. Expanded criteria donors for kidney transplantation. Am J Transplant. 2003; 3(Suppl 4): 114-225.

[17] Bertsimas D, Kung J, Trichakis N, et al. Accept or decline? An analytics-based decision tool for kidney offer evaluation. Transplantation 2017; 101: 2898-2904.

[18] McGregor E, Jardine AG, Murray LS, et al. Pre-operative echocardiographic abnormalities and adverse outcome following renal transplantation. Nephrol Dial Transplant. 1998; 13: 14991505 .

[19] Levin A, Thompson CR, Ethier J, et al. Left ventricular mass index increase in early renal disease: impact of decline in hemoglobin. Am J Kidney Dis. 1999; 34: 125-134.

[20] Ferreira SR, Moises VA, Tavares A, et al. Cardiovascular effects of successful renal transplantation: a l-year sequential study of left ventricular morphology and function, and 24-hour blood pressure profile. Transplantation 2002; 74: 1580-1587.

[21] Rangaswami J, Mathew RO, Parasuraman R, et al. Cardiovascular disease in the kidney transplant recipient: epidemiology, diagnosis and management strategies. Nephrol Dial Transplant. 2019; 34: 760-773.

[22] Zens TJ, Danobeitia JS, Leverson G, et al. The impact of kidney donor profile index on delayed graft function and transplant outcomes: a single-center analysis. Clin Transpl. 2018; 32: el3190.

[23] Gandolfini I, Buzio C, Zanelli P, et al. The Kidney Donor Profile Index (KDPI) of marginal donors allocated by standardized pretransplant donor biopsy assessment: distribution and association with graft outcomes. Am J Transpl. 2014; 14: 2515-2525.

[24] Arias-Cabrales C, Pérez-Sáez MJ, Redondo-Pachón D, et al. Usefulness of the KDPI in Spain: a comparison with donor age and definition of standard/expanded criteria donor. Nefrologia 2018; 38: 503-513.
(Nagy Ildikó,

Debrecen, Móricz Zs. krt. 22., 4032 e-mal: ildinagy10@gmail.com)

A cikk a Creative Commons Attribution 4.0 International License (https://creativecommons.org/licenses/by/4.0/) feltételei szerint publikált Open Access közlemény, melynek szellemében a cikk bármilyen médiumban szabadon felhasználható, megosztható és újraközölhető, feltéve, hogy az eredeti szerző és a közlés helye, illetve a CC License linkje és az esetlegesen végrehajtott módosítások feltüntetésre kerülnek. (SID_1) 